\title{
A STUDY OF THE FOREST AND AQUATIC ECOLOGY OF THE BITUMEN BELT OF OGUN STATE, NIGERIA
}

\author{
Z.O. Opafunso ${ }^{1}$ and J.O. Okunlola ${ }^{2}$ \\ ${ }^{1}$ Department of Mining Engineering, Federal University of Technology, Akure, Nigeria \\ ${ }^{2}$ Department of Agricultural Economics and Extension, Federal University of Technology, Akure, Nigeria
}

\begin{abstract}
A study of the forest and acquatic ecology of the bitumen belt of Ogun State, Nigeria was carried out. The status of the acquatic and wildlife species in the study area was investigated over a period of six months (January - June, 2005). The aim of the study was to identify and describe the type of wildlife and acquatic resources of the tar sand areas of Ogun State, Nigeria. The study was also carried out in order to identify some of the factors responsible for land cover and vegetation changes in the study area. Inventory of wildlife species was determined in the study area using a combination of methods like road count, variable transect belt, indirect indices, discussion with hunters and farmers, visits to bush meat processing centers and food vendors. The study shows that the aquatic environment of the study area is not very different from the aquatic environment in other parts of the rain forest region of Southern Nigeria. The impact of human activities was evident in the relative paucity of zooplankton and the larger aquatic fauna. However, the surface water bodies were still relatively rich in phytoplankton, as a result of the enrichment of the water bodies by decayed vegetable matter from the forests. Also, the massive deforestation that has taken place and has continued unabated in the tar sands area did not portent well for aquatic life in the study area. The proposed mining of bitumen in the study area will further increase the rate of deforestation and of the generation of sediments which may silt up the water channels and reduce their biological productivity.
\end{abstract}

Keywords: Bitumen, tarsands, ecology, wildlife, forest, acquatic

\section{INTRODUCTION}

American Society for Testing and Materials (ASTM, 1999) defined bitumen as a class of black or dark - colored solid, semisolid or viscous cementations natural or manufactured substances consisting principally of high molecular weight hydrocarbon of like asphalts, taps, pitches and asphaltenes. In general, tar sand is a sedimentary rock that contains, bitumen (solid or semisolid hydrocarbons) that cannot be recovered by conventional recovery methods. There are many propositions regarding the origin of this hydrocar- 
bon - rich material, such as formation from organisms living in the environment of the original sand deposits or evaporation of the older pooled oils after exposure on the surface (Link, 2001). Recent theories have however confirmed that tar sand is a resultant effect of water washing volatilization and severe biodegradation of conventional crude oil (Rubinstein et al, 2002).

Tar sand occurs in most continents of the world. In fact, the most conventional crude oil producing countries have also deposits of oil sands or tar sand. However, the Canadian deposits seem to be the most popular in terms of available literature on the characterization of the deposits as well as the production and utilization of the resulting synthetic crude (Carrigy, 1978; Hosternman, 2001). In Nigeria, tar sand belt occurs in Southwestern Nigeria along the Eastern Dahomey (Benin) basin, a marginal pull - apart or margin - sag basin (Adegoke et al, 1976). The tar sand outcrops are approximately $120 \mathrm{~km}$ long and $4-6 \mathrm{~km}$ wide extending from Ijebu Ife in Ogun State across Akotogbo area in Ondo State and Siloko, at the western margin of Edo State. The tar sand occurs within upper cretaceous sediments. They occur as tar impregnated rocks, tar pits and tar producing wells. Tar seepages have been recorded in these areas since the dawn of this century. The material was preliminarily assessed as a source of asphaltic material for road surfacing by various bodies; (Coursey, et $a l, 2001)$. Considerable exploration was carried out by defunct German firm, Nigerian Bitumen Corporation, between 1907 and 1914 and also by the Tennessee Nigeria Incorporated (Durham and Pickett, 1966).

Occurrence of tarsand seepages was reported at Okitipupa and Ijebu Ode areas in the colonial records as far back as 1900. The seepages were known and exploited locally for painting. Recorded occurrences were along the $120 \mathrm{~km}$ belt, stretching from Ijebu-Ode in Ogun State, through Akotogbo area in Ondo State and to Siloko in Edo State. In 1905, the then Colonial Mineral Survey of Southern Nigeria (MSSN) drilled Sixteen (16) shallow boreholes in the Western part of the belt. The defunct Nigerian Bitumen Corporation (NBC) drilled fifteen (15) wells in the bituminous zone between 1907 and 1914. All except boreholes 11 and 13 were drilled to the basement complex. They penetrated variable thickness of heavily impregnated sands and grids and recorded substantial occurrences of yellow sulphur. Unfortunately, the NBC wells were not properly or completely investigated.

The then Western Region Government, through its public works department, successfully used the natural bitumen to tar road by direct labour between 1938 and 1942. The defunct Gulf Oil Corporation of Pittsburgh, U.S.A. in 1954 examined samples from the belt and concluded that they were suitable for producing road surfacing asphalt mixes. Coursey et al (1973) and Federal Institute of Industrial Research, Oshodi, in 1973 at the request of the Western Nigerian Ministry of Trade and Industry carried out a serious study on the deposit. The report gave some technical data on the samples collected and recommended a few tones of the materials for trial road surfacing. IPCO of West Germany, in 1975, prepared a report containing a review of all the reported Mineral Resources occurrences including the bituminous sands in the South - Western Nigeria. The IPCO personnel visited Foriku and Agbabu and collected one sample only from Lagbojege village along River Oluwa. They produced:

(i) A "sand asphalt" by mixing $60.6 \%$ by weight of tar sand with $17.4 \%$ limestone screening (0.09$0.2 \mathrm{~mm}$.) and $22 \%$ by weight flour lime (less than $0.09 \mathrm{~mm}$.) and (ii) "Topeka"' type asphalt concrete by mixing $40-50 \%$ by weight tarsands with $13.3 \%$ limestone grit $(5.8 \mathrm{~mm}$.), $21.60 \%$ limestone screening and $22.5 \%$ flour lime (less than $0.09 \mathrm{~mm}$.). They were not able to successfully extract the bitumen using solvents or by heating. Based on the data in the two reports above, they reaffirmed that the tar sand deposit and the associated bitumen were suitable for road construction. They recommended experimental paving of one-kilometer stretch and subjecting this to nor- 
mal traffic for about one year.

Tennessee Nigeria Incorporated, with Oil Mining Lease (OML) 47, drilled a total of six (6) boreholes in 1963 with the aim of investigating the possibilities of primary or thermal recovering of low gravity (or heavy) oil occurring within the bitumen belt area (Durham and Pickett, 1966). OML 47 covered an area of about $156.20 \mathrm{~km}^{2}$ to the North East of Lekki Lagoon, Lagos, Nigeria. It overlaps partly the area earlier investigated by the defunct Nigerian Bitumen Corporation. The project by Tennessee Nigerian Incorporated failed because very low net pay sands were recorded and oil saturation of less than $70 \%$ was achieved. Based on the foregoing, the project was abandoned and the Oil Mining Lease was relinquished. The most intensive work carried out on the tar sand deposit occurrence in Nigeria was by the Geological Consultancy Unit of Obafemi Awolowo University, IleIfe in collaboration with TESCO of Hungary between 1974 and 1976. Their works involved, among others; core drilling, sedimentology, miropaleontogoical and clay mineral analysis. It was concluded that the bitumen layers were probably continuous in the sub-surface and were usable for a number of industrial applications, particularly as bitumen for road surfacing, roof sealing materials and as potential raw material for petrochemical industries (Adegoke, et al, 1974; Adegoke, et al, 1976; Adegoke, et al, 1978).

The Federal Government of Nigeria between 1989 and 1995, instituted a national "Committee on the Implementation of the Bitumen Project" (CIBP), to develop the resources, mainly based on earlier studies carried out by the Geological Consultancy Unity (GCU) of Obafemi Awolowo University. Ile-Ife, Nigeria. In a feasibility study commissioned by CIBP between 1990 and 1991, Brink Jones Nigeria Limited, concluded that there is a potential free-flow of bitumen at depth, with impregnated sand found in the deepest hole of about $80 \mathrm{~m}$. Test samples sent by the CIBP to Alberta Research Council
(ARC) of Canada in 1991 reached feasibility conclusion that the tar could be used directly as asphalt binder and could be upgraded to synthetic crude (Nigerian Bitumen Project Profile, 1997). With this conclusion, economic exploitation of the rich bitumen deposit of Ogun state, Nigeria is eminent.

Benneh (1992) opined that a few large animals are found in the rain forest of South west Nigeria. According to him, gorillas and chimpanzees in decreasing numbers are present, as well as baboons and monkeys. Reptiles abound, including crocodiles, lizards, and snakes of many species. Although many kinds of mammals can be found inland from the rain forest, these are not nearly so plentiful as in East or South Africa. Nigeria possesses two dozen species of antelope, but large concentrations of animals, even the common antelope, are rarely observed. The hippopotamus, elephant, giraffe, leopard, and lion now remain only in scattered localities and in diminishing number. Wildcats, however, are more common and widely distributed. Wildlife in the savanna includes antelope, lions, leopards, gazelles, and desert hyenas. Nigeria also abounds in bird life with a great number of species being represented. Ajayi (1990) also reported that in the South Western Nigeria, bush meat constitute $20 \%$ to $25 \%$ of the peoples animal protein.

The natural vegetation of Ogun State, Nigeria is divisible into two main sections directly related to the chief climatic regions of the country: (1) high forest, including both swamp and rain forests, and (2) savanna (Benneh, 1990). Along the coastal area of the state, the mangrove tree predominates, while immediately inland is freshwater swamp forest, which is somewhat more diversified and includes varieties of palms and mahogany. Principal trees include the African mahogany, iroko, African walnut, and the most popular export wood, the obeche. Farther inland, the rain forest becomes displaced by tall grass and deciduous trees of small stature, characteristic of the savanna. Of all the various forms of environmental degradation, the most insidious would seem to be 
devegetation and the attendant loss of flora, fauna and soil quality which, together with coastal erosion and water body sedimentation and putrefaction, may collectively be called land degradation. Lameed and Abimbola (2003) opined that the ecosystem of the northern part of Ogun State could be classified within derived savanna region, with flora and fauna natural resources under pressure of human utilization in form of shifting agricultural practice and sand mining. Site-specific species such as Elaeis guineensis, Cola spp. and Afzelia africana and others formed the major forest composition $[73.9 \%]$.

According to Benneh (1990), the biophysical environment forms a fundamental basis of human existence. It refers to the land, soils, water bodies, flora, fauna - the very air we breathe and the other resources of the biotic and abiotic world that surround human society and from which humanity derives a living. Basic human subsistence requirements are met from the land through farming, from the forests through hunting and gathering, and from the water bodies through fishing and water use for domestic, agricultural, industrial and other purposes. Each and every component of the natural environment bears significantly upon our livelihood. Furthermore, the environmental components interlink in a complex global ecosystem embodying many subsystems whose indiscriminate disruption would upset the delicate ecological balance with grave consequences for humankind. These pragmatic considerations, in addition to moral or ethical considerations, provide a compelling justification for the preservation of the natural integrity of the environment, by living harmoniously with it, as our ancestors apparently did. It is, therefore, imperative that the study of the forest and aquatic ecology of the bitumen belt of Ogun State, Nigeria be carried out as part of the mandatory environmental baseline study. This is the focus of this write-up.

\section{MATERIALS AND METHODS}

\section{Forest and Forest Ecology in the Study Area}

The forest ecological study was carried out to characterize the vegetation in the study area with respect to the status of the relics of the original rich tropical forest that once covered the area and the anthropic derivatives of the vegetation, that is, the various elements of land cover in the study area. Fig 1 shows the map of the study area

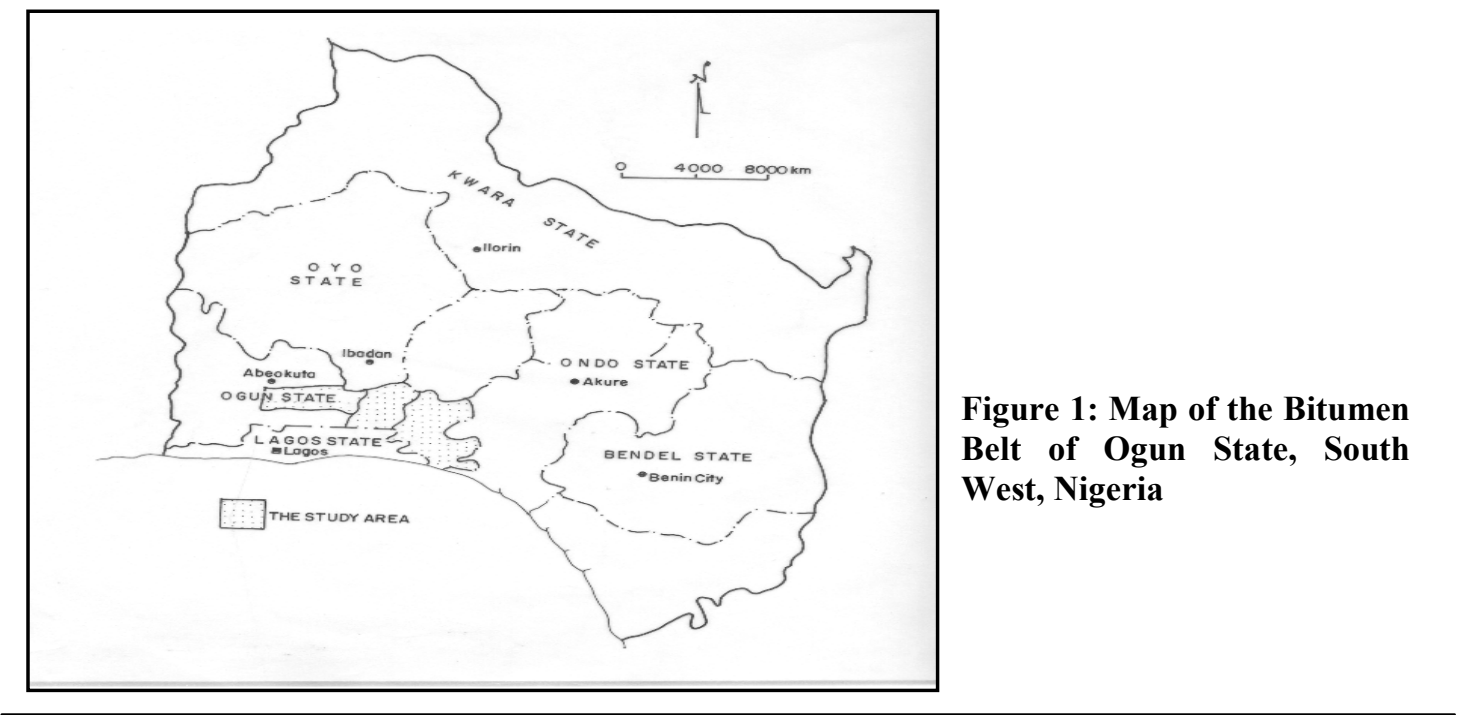

60 Journal of Science and Technology, Vol. 27, No. 3, December 2007 
which comprises of Odogbolu, Ijebu North East, and Ogun Water Side Local Government Areas of Ogun State. The study was also carried out to identify the factors of land cover/vegetation changes and the processes of change in the area, i.e. the dynamic ecology of the area. Two standard approaches to ecological field surveys were adopted for the collection of relevant data sets. These are the systematic randomized field observation and the case study approaches. The first approach was used to generate a broad data base on the characteristics of the vegetation and land use together with the factors that have modified or produced them. The study sites for the systematic randomized survey were chosen to reflect the basic geomorphologic units of the study area. The second approach was used primarily to fill-in the gaps in the data generated with the first approach. The cases selected for the study were relics of the original vegetation, i.e. secondary forests found in isolated locations such as hill tops and in relatively less disturbed valley floors. Others included a number of dominant land cover derivatives, including plantations of Havea brasiliensis (rubber) and Elaeis guineensis (oil palm).

\section{Wildlife Resources in the Study Area}

The status of the wildlife species in the study area was investigated over a period of six months (Jan - June, 2005). The aim of the study was to identify and describe the type of wildlife resources of the tar sand areas of Ogun State. The value of wildlife as environmental datum for lives and monitors of change, as well as their usefulness as agents for the restoration of damaged ecosystems was determined. The need to make an inventory of wildlife resources in the tar sand areas as a base line study for the effective exploitation of the bitumen deposit of Ogun State was also one of the reasons for the study. For effective coverage and reliability of information, the study area was divided into three as follows: Imeri - Yemoji axis, Abigi - Iwopin axis and Orino river - Oni river axis. Inventory of wildlife species was carried out in each unit using a combination of methods such as road count, variable transect belt, indirect indices, discussion with hunters and farmers, visits to bush meat processing centers and food vendors. The road count method involved wildlife species that crossed the road or that were loafing on either side of the road. The variable transect-belt method was employed in each of the three above designated axis. Each unit was criss-crossed after fixing a leg counter. Animals encountered were recorded. Animal spurs along the tracts, water holes, burrows and vests within $200 \mathrm{~m}$ of the traversed transect were identified and counted as indirect indices of wildlife species inventory. Vocalization of primates and surges of birds were equally used in the assessment. With the aid of binoculars, birds were identified along streams and rivers in farmlands in suburbs of faming enclaves and areas of the forest with open canopy. This division was made possible using the IjebuOde-Ore express road as the main transect.

\section{RESULTS AND DISCUSSION}

Forest and Forest Ecology

The original vegetation of study area falls into the tropical rain forest of Nigeria as described by Richards (2002). It is one of the richest and most luxuriant vegetation units in the world. According to Hepper (2003), this vegetation type in the West African sub-region (i.e. including the study area) has more than 3,000 woody species and several hundreds of the other categories of plants including lianas, climbers, epiphytes and saprophytes. The trees growing in the forest produce three distinct strata of crowns. The upper layer, which is discontinuous, is made up of emergent species. This layer reaches a height of $30 \mathrm{~m}$. A more continuous layer in which tree branches and leaves interdigitate succeeds the upper layer. The trees in the layers are shorter and or younger. The third layer is made up of shorter trees, which may be facultative heliophytes, being able to do well with the little amount of light that reaches them through the emergent and second strata. Below the third tree layer is the undergrowth, which harbours a wide range of herbaceous spe- 
cies, and climbers, many of which are obligatory heliophytes. Growth is profuse in this layer only in locations where light is able to penetrate the floor deeply.

\section{Relics of the Original Plant Cover}

Most of the characteristics described above have virtually disappeared. The original vegetation has been modified so much, both floristically and physiognomically, that it is hard to believe that a rich vegetation type actually covered the area in the past. However, the presence of relics has made it possible to confirm the characteristics of the original vegetation. The relics of relevance are the mature/developing secondary forests found in isolated locations along major rivers, such as "Oluwa' river, particularly towards the western parts. In many of these relics, such as the two found around Imeri, south of IjebuOde, where there is a massive outcrop of tar sand, the physiognomic characteristics described for tropical forest are not obvious, but the diversity of species found in them suggests a poten- tially rich forest if it were possible to withdraw human interferences particularly timber felling and cultivation. In one of the relics, 16 species of trees were identified over an area of about $30 \mathrm{~m}^{2}$. They are shown in Table 1 . The trees were between $8-15 \mathrm{~m}$ high. The understorey was dense wherever there was a deep penetration of light. Herbaceous species such as 'Mawo lolule' (Hippocratea spp) and Hipo cola (Paulina pinnata) were also common.

Many of the typical trees of the original forest were also found growing in isolation in many locations. These are the trees that for one reason or the other, have survived the effects of the factors of change particularly cultivation and tree felling. Such trees occur around settlements as shade trees or as one or two trees in large parcels of farmland. Valuable trees, particularly those which have medicinal use and/or provide food were also well protected in the area. The commonest trees in these categories are shown in Table1.

Table 1: Tree Species in the Study Area

\begin{tabular}{lcccc}
\hline Tree Species & Oruno & Oni & Iwopin & Imeri \\
\hline Wild rubber (Funtumia elastica) & $\mathrm{x}$ & $\mathrm{x}$ & $\mathrm{x}$ & $\mathrm{x}$ \\
Sand paper tree (Ficus exasperate) & $\mathrm{x}$ & $\mathrm{x}$ & $\mathrm{x}$ & $\mathrm{x}$ \\
False thorn albizia (Albizia ferruginea) & $\mathrm{x}$ & $\mathrm{x}$ & $\mathrm{x}$ & $\mathrm{x}$ \\
Flat crown albizia (Albizia glaberrima) & $\mathrm{x}$ & $\mathrm{x}$ & - & $\mathrm{x}$ \\
White silk cotton tree (Ceiba pentandra) & $\mathrm{x}$ & $\mathrm{x}$ & $\mathrm{x}$ & $\mathrm{x}$ \\
Hog plum (Spondias mombin) & $\mathrm{x}$ & $\mathrm{x}$ & $\mathrm{x}$ & $\mathrm{x}$ \\
Red oil palm (Elaeis guineensis) & $\mathrm{x}$ & $\mathrm{x}$ & $\mathrm{x}$ & $\mathrm{x}$ \\
Iroko tree (Milicia excelsa) & $\mathrm{x}$ & $\mathrm{x}$ & $\mathrm{x}$ & $\mathrm{x}$ \\
Lecaniodiscus (Lecaniodiscus cupanioides) & $\mathrm{x}$ & $\mathrm{x}$ & - & $\mathrm{x}$ \\
Mahogany (Khaya grandifolia) & $\mathrm{x}$ & $\mathrm{x}$ & $\mathrm{x}$ & $\mathrm{x}$ \\
Wild nut (Pycnanthus kombo) & $\mathrm{x}$ & $\mathrm{x}$ & $\mathrm{x}$ & $\mathrm{x}$ \\
Wild mango (Irvingia gabonensis) & $\mathrm{x}$ & - & $\mathrm{x}$ & $\mathrm{x}$ \\
'Oporoporo' (Cola gigantean) & $\mathrm{x}$ & $\mathrm{x}$ & $\mathrm{x}$ & $\mathrm{x}$ \\
'Aworiwo' (Cola laurifolia) & - & $\mathrm{x}$ & $\mathrm{x}$ & $\mathrm{x}$ \\
Axlewood (Anogeissus leiocarpus) & $\mathrm{x}$ & $\mathrm{x}$ & - & $\mathrm{x}$ \\
African hackberry (Celtis zenkeri) & $\mathrm{x}$ & $\mathrm{x}$ & $\mathrm{x}$ & $\mathrm{x}$ \\
Mawololule' (Hippocratea spp) & - & $\mathrm{x}$ & - & $\mathrm{x}$ \\
White afara (Terminalia superba) & $\mathrm{x}$ & - & $\mathrm{x}$ & $\mathrm{x}$ \\
Hipo cola (Paulina pinnata) & $\mathrm{x}$ & $\mathrm{x}$ & $\mathrm{x}$ & $\mathrm{x}$ \\
'Idigbo' (Terminalia ivorensis) & $\mathrm{x}$ & $\mathrm{x}$ & $\mathrm{x}$ & $\mathrm{x}$ \\
African star apple (Chrysophylum albidum) & - & $\mathrm{x}$ & - & $\mathrm{x}$ \\
\hline
\end{tabular}

62 Journal of Science and Technology, Vol. 27, No. 3, December 2007 


\section{Factors of Change}

The most factor of change that has overwhelmingly modified the original vegetation is cultivation. The cycles of cultivation remove the original plant cover and ensure that it does not reestablish itself. Associated with this are the cultivation of Havea brasiliensis and the establishment of red oil palm (Elaeis guineensis) plantations. These have taken over large expanses of land in the area. In places where cultivation has been less potent due to low population, the factor of change is timber felling. Trees were removed without replacement and because of the carelessness of the exploiters; many trees were usually destroyed in the attempt to extract a set of logs. Virtually all loggable trees had been removed from the forests. Since there is no deliberate policy of replacement, the forests had been over-exploited and in many of what remain as forest, small-sized woody plants dominate. As is to be expected, the species diversity was poor, the composition being not more than five species with Elaeis guineensis being the dominant species.

\section{Other Major Products (Land Cover Types) Of Change}

As already indicated, the vegetation of the area has over time been severely modified. The secondary forests were about the best that were available as natural vegetation. Apart from this, one can recognize the other dominant land cover as follows: (a) food crop mosaics; (b) tree crop mosaics; and (c) fallow lands.

\section{Food Crop Mosaics}

Food crop mosaic was a major land cover type in the tar sands area, particularly in the AgbabuOde-Irele axis. Musa spp (plantain and banana) are the most important crops. They were grown primarily for sale as food crop outside the region. Musa spp is either grown singly or in combination with some other crops, such as Manihot esculentus (cassava), Dioscorea spp (yam), Xanthosoma sp; Zea mays (maize) and Hibiscus esculentus. With the exception of
Musa spp all the food crops were commonly cultivated close to settlements. The overwhelming suitability of the environment for the cultivation of plantain and banana and the fact that fruiting of these crops can be monitored over a longer period, explain the ubiquity of the crops in the area. A common characteristic of the farms is their small sizes with each farm hardly covering up to 0.4 ha. In many cases, food crop farms frequently appear as the last phase in the transition from rubber plantations to food crop farms.

\section{Tree Crop Mosaics}

Tree crop mosaics were important anthropic vegetation unit in the tar sands area. It is possible to recognize at least three tree crop mosaics as follows:

Cocoa/Kola Citrus Mosaic: Particularly close to the ocean on the Eocene formations, the soils of the area are generally too freely-drained for cocoa, citrus and kolanut plantations. It appears, however, that the abundance of rainfall is satisfactorily compensating for the rapid soil water loss, creating a moderately suitable environment for the tree crops. The cocoa/kolanut/citrus mosaic fell into two categories. The first is one in which kolanut appears to be succeeding cocoa, while the second, which is composed of young cocoa trees and kolanut were either absent or not prominent. Most of the units of this mosaic were also found in close proximity to settlements. The fields were characteristically small but well kept. A number of forest trees were encouraged on the tree crop farms and these towers above the crowns of the tree crops. Otherwise, the biomass of this mosaic was relatively light and was not up to that of a re-established secondary forest at its early stages of development.

Oil Palm Mosaic: These mosaics were produced by the random cultivation of palm trees by smallscale farmers and by the natural ability of the tree to multiply itself. The small-scale farmers' holdings occur in small patches but the aggregate of these was significant although the actual real ex- 
tent was difficult to estimate. The plantations were closely managed as no other trees were allowed to develop in them. In gaps between stands of Elaeis guineensis, one could find thick patches of Chromolaena odorata as the second dominant plant. It was observed in the field that many of the small farms were developed as a replacement for Havea brasiliensis farms. Local farmers indicated that this was a reaction to the declining economic importance of rubber.

Many decades ago when Havea brasiliensis was an attractive and profitable tree crop, large areas of the region were cultivated with the tree. The holdings were small but because many farmers were engaged in the planting, a landscape dominated by $H$. brasiliensis soon developed. The downturn in the economic fortune of this cash crop within the Nigerian economy affected its area of coverage. Thus, it was not as continuous as it was some decades ago. Although the total coverage was still large and significant in terms of the overall land cover, the tree now appears mainly in small parcels of land. The trees were characteristically old, averaging up to $1 \mathrm{~m}$ at breast height in many fields and towering well above $15 \mathrm{~m}$. However, tapping of the trees is widely irregular and desultory which is a confirmation of the low contemporary value of the rubber latex. Rubber farms were characteristically monospecific. They were spaced in such a way that other trees find it difficult to establish in them. With age, however, the continuity is broken and trees such as Elaeis guineensis come in as successors in poorly managed fields. The future of the plantations is not very promising and oil palms and food crops may soon take them over completely.

Fallow Lands: The fallow lands were de facto part and parcel of the cropland mosaics because they were left fallow for subsequent cropping seasons. They were separated from the crop mosaics because they carry a distinctive plant cover. Chromolaena odorata dominated, especially in young fallows of one year or so. Trees such as Vernonia amygdalin and Gliricidia sepium were also very common. The fallow lands were very common in the areas close to the settlements. In most places the fallow lengths had become very short. Some of the farmers interacted with said that the fallow period is now hardly more than three years. Consequently, it is the areas of extensive food cropping that stand out distinctly in the tar sands areas.

\section{Wildlife Resources in the Study Area}

Table 2 shows the wildlife species in the study area. The Abigi - Iwopin area was spectacular for the large number of grasscutters captured by farmers. There was even a wildlife keeper who possessed Genetta civetta (civet cat), Viverra civetta (geret cat), Veranus niloticus (monitor lizard), brushed tailed porcupine and giant rat among his collections. Wildlife species were not seen in the Imeri - Yemoji axis and the communities were not sure of when these resources were last seen in the area. With the exception of the flying squirel, grasscutter, tree squire, snail, agama lizard and red-headed lizard, that were directly sighted in the field, all other species listed emanated from the information received from farmers and hunters on their recent bag composition. In case of the gray duiker, the faeces was identified in the field while most food vendors specialized in grasscutter, grey duiker and porcupine dishes. Table 3 shows that out of the bird species sighted in the study area, the bulbul occurred in all the units while the forest robin was most common around Ominla, Oruno and Omititun rivers. The grey heron which occurred in the Abigi-Iwopin axis was restricted to a small stagnant water body just before the boundary of Gmelina arhorea plantations.

The Oluwa and Omo Forest reserves are directly located to the north of the study area and it is probable that most of the wild animals and birds have taken refuge in the reserves to avoid human persecution and habitat destruction in the open areas. A survey of the Omo Forest reserve carried out by Amubode (1996) showed that 43 
Table 2: Wildlife Species in the Study Area

\begin{tabular}{|c|c|c|c|c|c|}
\hline \multirow{2}{*}{$\begin{array}{l}\text { Wildlife Species } \\
\text { Mammalian Fauna: }\end{array}$} & \multirow[t]{2}{*}{ Oruno } & \multirow[t]{2}{*}{ Oni } & \multirow[t]{2}{*}{ Iwopin } & \multicolumn{2}{|c|}{ Imeri } \\
\hline & & & & & \\
\hline Elephant (lexodonta Africana) & - & & - & - & $\mathrm{x}$ \\
\hline Buffalo (syncerus caffer) & - & & - & - & $\mathrm{x}$ \\
\hline Bush Pig (Pontamochoerus porcus) & - & & - & - & $\mathrm{x}$ \\
\hline Bush buck (Tragelaphus scriptus) & - & & - & - & $\mathrm{x}$ \\
\hline Grasscutter (Thryonomys swinderiannus) & $\mathrm{x}$ & & $\mathrm{x}$ & $\mathrm{x}$ & $\mathrm{x}$ \\
\hline Grey Duiker (Cephalphus monticola) & - & & $\mathrm{x}$ & - & $\mathrm{x}$ \\
\hline Yellow-backed Duiker (Cephalophus spp) & - & & - & - & $\mathrm{x}$ \\
\hline Maxwell Duiker (Cephalophus Maxwell) & - & & - & - & $\mathrm{x}$ \\
\hline Mona Monkey (Cercopithoadae spp) & $\mathrm{x}$ & & - & - & $\mathrm{x}$ \\
\hline White Throated Monkey (Cercopithoadae spp) & - & & - & - & $\mathrm{x}$ \\
\hline Brush-tailed Porcupine (Antherrorus africanus) & - & & - & - & $\mathrm{x}$ \\
\hline Giant Rat (Cricetomys gambianus) & - & & $\mathrm{x}$ & $\mathrm{x}$ & $\mathrm{x}$ \\
\hline Ground Squirrel (Xerus erythropus) & $\mathrm{x}$ & & $\mathrm{x}$ & - & - \\
\hline Hare (Lepus species) & - & & - & - & $\mathrm{x}$ \\
\hline Civet Cat (Mandinia spp) & - & & $\mathrm{x}$ & - & $\mathrm{x}$ \\
\hline Genet Cat (Felix libyca) & - & & $\mathrm{x}$ & - & $\mathrm{x}$ \\
\hline Benin Genet (libyca spp) & - & & - & - & $\mathrm{x}$ \\
\hline Shrew (soricidae spp) & - & & - & - & $\mathrm{x}$ \\
\hline Hedge Hog (Erinacidae) & - & & - & - & $\mathrm{x}$ \\
\hline \multicolumn{6}{|l|}{ REPTILES } \\
\hline Monitor Lizard (Varanidae spp) & - & & $\mathrm{x}$ & - & - \\
\hline Agama Lizard (Agamide spp) & - & & $\mathrm{x}$ & $\mathrm{x}$ & - \\
\hline Red Headed Lizard (Varanidae spp) & - & & $\mathrm{x}$ & $\mathrm{x}$ & - \\
\hline Iguana (Amblyrhynchis cristatus) & - & & - & - & $\mathrm{x}$ \\
\hline Tortoise (Order chelonian) & $\mathrm{x}$ & & - & $\mathrm{x}$ & $\mathrm{x}$ \\
\hline Boar (Boldae family) & $\mathrm{x}$ & & - & $\mathrm{x}$ & - \\
\hline Python (Pythonidae spp) & $\mathrm{x}$ & & - & $\mathrm{x}$ & - \\
\hline \multicolumn{6}{|l|}{ Gastropods: } \\
\hline Tilapia (Tillapia Zilli) & $\mathrm{x}$ & & - & $\mathrm{x}$ & - \\
\hline Water Snapper (Heterotis Niloticus) & $\mathrm{x}$ & & - & $\mathrm{x}$ & - \\
\hline Chrysichthys (Chrysichtys Nigroductatus) & - & & $\mathrm{x}$ & $\mathrm{x}$ & - \\
\hline Mudfish (Clarias Garicpinus) & $\mathrm{x}$ & & - & $\mathrm{x}$ & - \\
\hline $\mathrm{X}=$ present & & & & & \\
\hline$-\quad=$ absent & & & & & \\
\hline
\end{tabular}

mammalian fauna species, 13 reptiles and 3 other species were found.

\section{Aquatic Ecology of the Study Area Qualitative Analysis of Plankton}

The planktonic organisms observed in plankton samples collected in each station are shown in Table 4. The table shows that phytoplankton were more in number than zooplankton at the stations. Thirty-nine (39) genera of phytoplankton were obtained compared with nineteen (19) zooplankton species giving a phytoplankton to zooplankton ratio of 2.1. Table 4 further shows that the blue-green algae was dominant among the phytoplankton followed by the green algae while the diatoms Bacillariophyceae and the Zygnemaphyceae had very low counts. 
Table 3: Bird Species Sighted in the Study Area

\begin{tabular}{lcccc}
\hline Bird Species & \multicolumn{2}{c}{ Locations } & & \\
\hline Oruno & Oni & Iwopin & Imeri \\
\hline Method Kite (Milvus migminus) & $\mathrm{x}$ & $\mathrm{x}$ & $\mathrm{x}$ & $\mathrm{x}$ \\
Palm Swift (Cypsicutus parous) & - & - & $\mathrm{x}$ & - \\
Grey Heron (Ardea cinerea) & - & $\mathrm{x}$ & $\mathrm{x}$ & - \\
Collard Sunbird (Anthreptes sellaria) & - & - & $\mathrm{x}$ & - \\
Double Crested Francolin & - & - & $\mathrm{x}$ & - \\
(Franconotus xanthopygos) & - & - & $\mathrm{x}$ & $\mathrm{x}$ \\
Bearded Bulbul (Pysnonotidae spp) & $\mathrm{x}$ & $\mathrm{x}$ & $\mathrm{x}$ & $\mathrm{x}$ \\
Common Bulbul (Pycnonotus xanthopygos) & $\mathrm{x}$ & $\mathrm{x}$ & $\mathrm{x}$ & $\mathrm{x}$ \\
Forest Robin (Cosypha spp) & $\mathrm{x}$ & $\mathrm{x}$ & $\mathrm{x}$ & $\mathrm{x}$ \\
X= sighted & & & & \\
$-\quad=$ not sighted. & & & & \\
\hline
\end{tabular}

\section{Quantitative Analysis of Plankton}

Thirty-nine genera of phytoplankton were recorded. These were dominated by the bluegreen. Algae, especially Oscilloria limosa in SW1 - 5 and SW 8-9 with counts varying from 420 to 7400 cells/ml; Anacystis sp. (SW1 - SW5 and SW8) and Polycystis (SW7, SW9 and SW10). The green algae was dominated by $\mathrm{Hy}$ drodictyton and Membraniphora sp. With low counts of 20-30 cells $/ \mathrm{ml}$ in Ankistrodesmuts $s p$. (SW5, SW7 and SW8). The diatoms species obtained included navicula $s p$. with counts ranging from $10-40$ cells $/ \mathrm{ml}$ in all stations except SW7 and SW10. Nitzchia had counts of between 10 and 60 cells in SW1, SW2 and SW8. Melosira $s p$ was present only in Oruno river (SW6) as 100 cells $/ \mathrm{ml}$. The zooplankton counts obtained were low compared to the phytoplankton. One to three species were found in each site except Agbabu Jetty sample (SW1) which had 8 species. Cyclops sp was found in Ominla (SW3) and Omititun (SW4) rivers having between 10 and 20 individuals per mililitre. Tyropocyclops were found in Owun river, and Protozoa were found in 3 stations, SW1, SW4 and SW10.

\section{Aquatic Macrophytes}

Floating aquatic macrophytes were observed in three sampling sites, namely: Agbabu Jetty (SW1), Omititun River (SW4) and Iwoping road (SW8). These were floating mats of grasses (Cyperaceae) almost covering the water channel in Agbabu Jetty. Also present were Pistia stratiotes, Nymphea lotus and submerged long strands of Ceratophylum.

Omititun River: The floating aquatic macrophytes consisted of Pistia stratiotes, Nymphea lotus, and Ipomea aquatica.

Iwopin Road: The whole of the water surface was almost covered by Pistia stratiotes and Nymphea lotus. Lemna sp were also found at the site. Table 4 shows that marginal aquatic plants were however noted in SW1, SW4, SW8, SW9 and SW10.

\section{Aquatic Survey}

The results obtained in the field survey of the water bodies are shown in Table 4. The Table shows that the water bodies can be classified into 3 categories, viz: 
Table 4: Plankton Diversity and Abundance (No. of individuals per Millilitre)

\begin{tabular}{|c|c|c|c|c|c|c|c|c|c|c|}
\hline Phytoplankton & SW1 & SW2 & SW3 & SW4 & SW5 & SW6 & SW7 & SW8 & SW9 & SW10 \\
\hline \multicolumn{11}{|l|}{ CYANOPHYCEAE } \\
\hline Oscillatoria foremosa & & 4600 & - & 620 & - & - & - & - & 410 & - \\
\hline O. limosa & 1060 & 570 & 1920 & 520 & 420 & - & - & 7400 & 1600 & - \\
\hline Lyngbya sp. & - & - & - & - & - & - & 630 & - & 1300 & - \\
\hline Anacystis & 2100 & 8200 & 8000 & 1170 & 1080 & - & - & 2800 & - & - \\
\hline Polycystis & - & - & - & - & - & - & 9030 & - & 9000 & 7000 \\
\hline \multicolumn{11}{|c|}{ CHLOROPHYCEAE } \\
\hline Oedogonium & - & - & 60 & 90 & 60 & - & - & - & 60 & - \\
\hline Hydrodictyon & 180 & 410 & 600 & 860 & 820 & 480 & - & 860 & - & 650 \\
\hline Excentrosphaera & 40 & - & - & - & 20 & - & 760 & - & 3200 & - \\
\hline Botryococcum & 3800 & - & - & - & - & - & - & - & - & - \\
\hline Membraniphora & - & 1260 & 890 & 540 & 600 & - & - & - & - & 1080 \\
\hline Tribonema & - & 130 & - & - & 320 & 60 & - & - & - & - \\
\hline Cladophora & - & - & 420 & - & - & - & - & - & - & - \\
\hline Microspora & - & - & 380 & - & - & - & - & - & - & - \\
\hline Ankistrodesmus & - & - & - & - & 20 & - & 10 & 30 & - & - \\
\hline Crucigenia & - & - & - & - & - & 20 & - & - & - & - \\
\hline Cerasterias irregulare & & - & 60 & 20 & 20 & 10 & - & - & - & - \\
\hline \multicolumn{11}{|c|}{ ZYGNEMAPHYCEAE } \\
\hline $\begin{array}{l}\text { Clasterium } \\
\text { monilifoerme }\end{array}$ & & 10 & 10 & 0 & - & - & - & - & - & - \\
\hline C. acerosum & 10 & - & - & - & - & - & - & - & - & 10 \\
\hline C. rostratum & 10 & - & - & - & - & - & - & 10 & - & - \\
\hline Pleurotaenium & - & 20 & - & - & - & - & - & - & - & - \\
\hline Mongeotia viridis & & - & - & - & 180 & - & - & - & - & - \\
\hline Spirotaenia & - & - & - & - & 30 & 40 & - & 20 & - & 20 \\
\hline Closterium sp & - & - & - & - & - & - & - & - & - & - \\
\hline Phytoplankton & SW1 & SW2 & SW3 & SW4 & SW5 & SW6 & SW7 & S38 & SW9 & SW10 \\
\hline \multicolumn{2}{|c|}{ BACILLARIOPHYCEAE } & - & - & - & 60 & - & - & - & - & - \\
\hline Navicula sp. & 30 & 40 & - & 20 & 20 & - & 20 & 10 & 20 & - \\
\hline N. indifferens & 10 & - & - & - & - & - & - & - & 10 & - \\
\hline N. subrhyncocephala & & - & - & - & - & - & - & 10 & - & - \\
\hline Melosira & - & - & - & - & - & 100 & - & - & - & - \\
\hline M. granulate & - & 20 & 230 & - & - & 140 & - & - & - & - \\
\hline Biddulphia & - & 10 & - & 30 & - & - & - & - & - & - \\
\hline Eunotia & 10 & - & - & - & - & - & - & 10 & - & - \\
\hline E. tchirschiana & 20 & - & - & - & - & - & - & - & - & - \\
\hline Amphora veneta & 10 & - & - & - & - & - & - & - & - & - \\
\hline Gomphonema & 10 & - & 20 & & - & - & - & - & - & - \\
\hline Gyrosigma & - & - & - & - & - & - & 30 & - & - & - \\
\hline Nitzchia & 60 & 10 & - & - & - & - & - & 10 & - & - \\
\hline Pinnularia & - & - & - & - & - & - & - & 30 & 10 & - \\
\hline P. dubia & - & 10 & - & - & - & - & - & - & - & - \\
\hline Diatoma & - & - & - & - & - & - & - & - & 30 & - \\
\hline $\begin{array}{l}\text { Cyclotella } \\
\text { opereculata } \\
\text { ZOOPLANKTON } \\
\text { ROTATORIA }\end{array}$ & & - & 10 & - & - & - & - & - & - & - \\
\hline Pleaurotrocha & - & - & - & - & - & - & - & - & - & 10 \\
\hline Rotaria & 20 & 20 & - & - & - & - & - & 10 & - & - \\
\hline
\end{tabular}


A study of the Forest and Aquatic ecology ...

Opafunso and Okunlola

\begin{tabular}{|c|c|c|c|c|c|c|c|c|c|c|}
\hline Phytoplankton & SW1 & SW2 & SW3 & SW4 & SW5 & SW6 & SW7 & SW8 & SW9 & SW10 \\
\hline Brachiorus patulus & & - & - & - & - & 20 & 10 & - & - & - \\
\hline Lecane luna & 10 & - & - & - & - & - & - & - & - & - \\
\hline L. papuana & 20 & - & - & - & - & - & - & - & - & - \\
\hline Lecane & 10 & - & - & - & - & - & - & - & - & - \\
\hline Keratella & 10 & - & - & - & - & - & - & - & - & - \\
\hline Trochosphaera & - & - & 10 & - & - & - & - & - & - & - \\
\hline Tetrasiphon & - & - & - & - & - & 10 & - & - & - & - \\
\hline Eggs & 60 & - & - & - & 20 & 30 & - & - & - & - \\
\hline \multicolumn{11}{|l|}{ PROTOZOA } \\
\hline Peridinium & 10 & - & - & - & - & - & - & - & - & - \\
\hline Arcella vulgaria & & - & - & - & 20 & - & - & - & 10 & - \\
\hline Volvox & 10 & - & - & - & - & - & - & - & - & - \\
\hline \multicolumn{11}{|l|}{ CRUSTACEA } \\
\hline Cypria & - & - & - & - & 10 & 10 & - & 10 & - & 10 \\
\hline Eubosmina sp. & 10 & - & - & 10 & - & - & - & - & - & - \\
\hline Cyclops & - & - & 20 & 10 & - & - & - & - & - & - \\
\hline Tropocyclops & - & - & - & - & 10 & - & - & - & - & - \\
\hline Bosmina longirostris & & - & - & - & - & 10 & - & - & - & - \\
\hline Monia sp. & & - & - & - & - & - & 10 & 20 & - & - \\
\hline \multicolumn{11}{|l|}{ INSECTA } \\
\hline Immature stages & & - & 20 & 10 & - & - & - & - & 20 & - \\
\hline Total No of Individuals & 12430 & 10940 & 13170 & 3540 & 3490 & 920 & 10510 & 11320 & 15640 & 8780 \\
\hline
\end{tabular}

per $\mathrm{ml}$. for each station. $\mathrm{SW}=$ Surface water

$\mathrm{GW}=$ Ground water

a) open rivers - SW1, SW3, SW6, SW7

b) rivers with forest cover - SW4, SW5, SW8, SW10; and

c) streams formed as outflows of spring water from the ground in the tar sand belt -SW2, SW9.

The nature of the substrate and general habitat conditions studied are also shown in Table 4. Boulders and large stones were observed in SW3 (Ominla River); Coarse stones predominated in SW4 (Omititun River); while sand and mud deposits with varying proportion of silt clay were observed in the other stations. Decaying organic debris were noted in sediments of SW1, SW4 and SW8 (Iwopin Road River) while leaf litter contributed appreciably to the sediments in SW5 (Owun River) and SW9 (Imeri village spring outflow). Low water levels due to the dry season also exposed sediments in some areas which were covered by blue green algae mat (Oni River), green filamentous algae in SW3, SW4 and SW6 (Oruno River). Tadpoles and insect larvae were observed at SW3 (Omititun River). The sediment samples were poor in benthic organisms. Fishing activities were not noticed at any station. Fish species observed in the waters included Tilapia zilli and Hemicromis sp in SW1, SW3 and SW7 while Tilapia and Clarias sp were observed in SW10.

\section{Index of Diversity (Margalef Index) at Each Station}

Table 5 shows that the index of diversity was highest in Agbabu Creek (SW1 with 2.54 followed by Owun and Omititun Rivers with 1.83 and 1.59 respectively. Yemoji River (SW10) had the lowest index of diversity value of 0.66 .

\section{Microbiological Studies}

Table 6 shows the total viable bacteria count (tvc) in surface water samples. The total viable bacteria count (TVC) varied from $830 \mathrm{cfu} / \mathrm{ml}$ in SW9 (Imeri village spring outflow) to $580 \times 10^{3} \mathrm{cfu} / \mathrm{ml}$ in SW4 (Omititun River). The TVC in the water 
Table 5: Index of Diversity (Margalef Index) at Each Station

\begin{tabular}{llc}
\hline Station & Location & Index of Diversity \\
\hline SW1 & Agbabu Jetty & 2.54 \\
SW2 & Ilubirin Ajaiyeka & 1.61 \\
SW3 & Ominla River & 1.26 \\
SW4 & Omititun River & 1.59 \\
SW5 & Owun River & 1.83 \\
SW6 & Oruno River & 1.46 \\
SW7 & Oni River & 0.75 \\
SW8 & Iwopin Road River & 1.49 \\
SW9 & Imeri Spring Outflow & 0.93 \\
SW10 & Yemoji River & 0.66 \\
\hline
\end{tabular}

Table 6: Total Viable Bacteria Count (TVC) in Surface Water Samples

\begin{tabular}{|c|c|c|}
\hline Station & Location & TVC cfu./ml x 10 \\
\hline SW1 & Agbabu Jetty & 2.00 \\
\hline SW2 & Ilubirin Ajaiyeka & 119.00 \\
\hline SW3 & Ominla River & 28.00 \\
\hline SW4 & Omititun River & 580.00 \\
\hline SW5 & Owun River & 46.00 \\
\hline SW6 & Oruno River & 84.00 \\
\hline SW7 & Oni River & 1.06 \\
\hline SW8 & Iwopin Road River & 69.00 \\
\hline SW9 & Imeri Spring Outflow & 0.83 \\
\hline SW10 & Yemoji River & 1.43 \\
\hline
\end{tabular}

samples are due to the mineralization of the decaying organic matter in them. The low value for SW9 may be due to low human activity from the spring source to the stream. The filamentous algae on the sandstones were mainly blue green and green algae which probably improved aeration of the water and resulted in the low bacteria count. Values obtained in the water samples were similar to those of natural water bodies that do not suffer from inputs of pollutants.
Table 7 shows the total viable bacteria count (tvc) in underground water samples The well water samples, GW1 - GW3, contained coliform ranging from 94 colonies $/ 100 \mathrm{ml}$ in GW3 to 540 colonies $/ 100 \mathrm{ml}$ in GW1 showing that the water samples are unfit as potable drinking water. The spring water samples, with one exception (GW7), contained less than 2 coliform while the borehole water sample at Ode-Irele contained 7 coliform $/ 100 \mathrm{ml}$. The spring water samples contained 
Table 7: Total Viable Bacteria Count (TVC) and Coliform Count in Ground Water Samples

\begin{tabular}{lllc}
\hline Station & Location TVC in cfu/ml x 10 & \multicolumn{2}{l}{ Coliform Count in MPN/100ml } \\
\hline GW1 & Well at Agbabu & 165.0 & 540 \\
GW2 & Agbabu Jetty Well & 260.0 & 280 \\
GW3 & Well at Ilubirin & 830.0 & 94 \\
GW4 & Spring & 490.0 & 2 \\
GW5 & Ode-Irele Borehole & 78.0 & 7 \\
GW6 & Legbogbo Spring & 550.0 & $<2$ \\
GW7 & Loda Spring & 240.0 & 22 \\
GW8 & Imeri Station-1 & 940.0 & 2 \\
GW9 & Imeri Station-2 & 69.0 & $<2$ \\
\hline
\end{tabular}

fewer coliform and with proper handling will be fit for drinking. The only spring water that contained 22 coliform was GW7, at Loda. This was possibly due to the farming activities nearby.

\section{CONCLUSION}

The study of the forest and aquatic ecology of the bitumen belt of Ogun State, Nigeria has been carried out. The study shows that the aquatic environment of the study area is not very different from the aquatic environment in other parts of the moist forest region of southern Nigeria. The impact of human activities is evident in the relative paucity of zooplankton and the larger aquatic fauna. But, the surface water bodies are still relatively rich in phytoplankton, thanks to the enrichment of the water bodies by decayed vegetable matter from the forests. Thus, the massive deforestation that has taken place and that has continued unabated in the tar sands area does not portent well for aquatic life in the area. Mining of any type will further increase the rate of deforestation and of the generation of sediments which may silt up the water channels and reduce their biological productivity.

\section{ACKNOWLEDGEMENT}

The contribution of Mr. Gbenga Familoni in the area of data collection is hereby acknowledged.

\section{REFERENCES}

Adegoke, O.S; Ako B,D; Omatsola, M.E; and Rahaman M.A (1974). Preliminary Proposal for the Exploration and Utilization of Tarsands of Western State of Nigeria Unpublished Report, Geological Consultancy Unit, Department of Geology, University of Ife, Ile-Ife, Nigeria, pp 66-69.

Adegoke, O.S; Ako B.D; Omatsola ,M.E; and Rahaman, M.A (1976). Tarsand Project Phase II, Estimation of Reserves, Materials Testing and Chemical Analyses, Unpublished Report, .Geological Consultancy Unit, Department of Geology, Obafemi Awolowo University, Ile-Ife, Nigeria, 155p.

Adegoke, O.S; Ako B.D; Omatsola ,M.E; and Rahaman M.A (1978). Tarsand Project Phase II, Delineation of Potential Report, Geological Consultancy Unit, Department of Geology, University of Ife, Ile-Ife, Nigeria, 60p.

Ajayi S.S (1990). Planning for Wildlife Management in Nigeria, Nigerian Field, p33

Amubode, F. O (1996). Assessment of Wildlife Species Diversity in Omo Biosphere Reserve, Nigeria, Nigerian Journal of Tropical Agriculture, Vol. 3, No1, pp $12-13$.

ASTM, (1999). American Society for Testing and Materials, Terms Relating to Material for

70 Journal of Science and Technology, Vol. 27, No. 3, December 2007 
Road and Pavements, ASTM Designation D8, Philadelphia, USA.

Benneh, G. (1990). Towards Sustainable Development: an African Perspective, Geografisk Tidsskrift 90, pp14-15.

Benneh, G. (1992). Systems of Agriculture in Tropical Africa, Economic Geography 48 (3): pp 57-59.

Carrigy, M.A (1978). Some Sedimentary Features of the Athabasca Oil Sands, Sedimentary Geology, Vol.5, No1, pp 327-352.

Chilingarian, G.V and Yen, T .F (1978). Bitumen, Asphalts and Tarsands Development in Petroleum Science 7, Elsevier Scientific Publication .Co. Amsterdam, 331p.

Coursey R.Y, Hubbard B.P and Hitch B.O (2001). Crude Oil and Tar Sand Exploration, Crockett and Westcott Publishers, Canada, pp56-59.

Coursey D.G; Hubard F.H and Hitch 1..S and the Federal Institute of Industrial Research (1973). Preliminary Observations on the Tarsands deposits of Western Nigeria Resources Report No 18, Federal Ministry of Commerce and Industry, Lagos, Nigeria, pp3-10.

Durham K.N and Pickett C.R (1966). Oil Mining Lease 47, Lekki Core Hole Programme (February -April 1966), Unpublished Report, Tennessee Nig. Inc., pp15-20.

Federal Institute of Industrial Research, (2003). Chemical Composition of Nigeria Bitumen, Report of Federal Institute of Industrial Research, Oshodi, Nigeria, pp 56-59.
Hepper G.T (2003). West African Vegetation, Macmillan Publishers, Lagos, Nigeria, pp1314.

Hosternman B.W (2001). Characterization of Canadian Tarsand Deposits, Proceedings of International Athabasca Tarsand Oil Conference, Alberta, pp 31- 42.

Lameed G.A and Abimbola O.A. 2003. Biodiversity Assesment of High Rain Forest Under Human Activities: A Case Study of Erinle Forest in Ogun State, Nigeria, Journal of Environmental Extension, Vol.4, P1.

Link T.A (2001). Source of Oil in the Oil Sand of Alberta, Proceedings of International Athabasca Tarsand Oil Conference, Alberta, pp 76-87.

Reyment R.A (1965). Aspects of the Geology of Nigeria, Ibadan University Press, Nigeria, 133p.

Reyment R. A (1995). The Cretaceous Ammonoidea of Southern Nigeria and the Southern Cameroon, Geol Survey of Nigeria Bulletin, No $.25,115 \mathrm{p}$.

Richards A.D (2002). Vegetation of Tropical Rain Forest of Nigeria, Nigerian Journal of Tropical Agriculture, Vol. 8, No3, pp34-35.

Rubinstein I, Strausz O.P; Spyckerelle, C; Crawford, R.J and Westlake, O.W (2002). The Origin of the Oils and Bitumen of Alberta: A Chemical and Microbial Study, Geochim Cosmchin Acta, Vol. 41 pp 1341-1351.

The Nigerian Bitumen (Tarsand) Project Profile (1997). Btumen Project Report, Ministry of Solid Minerals Development, Abuja, Nigeria, 276p. 